\title{
Analysis of Padang City community preparedness to face the earthquake and tsunami disaster
}

\author{
Diva Syandriaji ${ }^{1}$ and Junaidi ${ }^{1 *}$ \\ ${ }^{1}$ Department of Civil Engineering, Andalas University, Padang, Indonesia.
}

\begin{abstract}
Padang, West Sumatra is located in the collision area of two tectonic plates, namely IndoAustralia and Eurasia. Which is marked by the presence of a tectonic earthquake center in the Mentawai islands and surroundings. Realising the high risk of disasters, the people of Padang city must be ready and prepared for the possibility of an earthquake and tsunami. To reduce the risk of disaster, the use of "self-help" and "mutual-help" parameter might be the best way to help the people to know "what should they do?" and "how can they do it?" to protect themselves from disasters. This research aims to analyse the Padang city community's preparedness to face the Earthquake and Tsunami disaster by using "self-help" and "mutual-help" parameters. A questionnaire consisting of 20 questions was used to collect the data. The sample size of this research is 400 . The data was collected from 4 different areas (Random area, Pondok area, Purus area, and Ulak Karang area). The study found that the Padang city community might not be prepared to face the earthquake and tsunami disaster in the future in terms of self-help and mutual help as most of the items mentioned in the questionnaire have not been applied. The government is urged to develop appropriate policies regarding further disaster risk reduction
\end{abstract}

\section{Introduction}

Indonesia is known as a disaster-prone country because this country is surrounded by the Pacific Ring of Fire and is above three continental plate collisions, namely IndoAustralia, Eurasia, and the Pacific plate [1]. Most Indonesian provinces and their coastal areas are identified as "disaster-high risk," yet more than half of the total population live and are dependent on these areas [2]. West Sumatera is one of the disaster high-risk Province in Indonesia. This province is located in the collision area of two tectonic plates, namely Indo-Australia and Eurasia, and marked by the presence of a tectonic earthquake center in the Mentawai islands and surroundings. Padang city, the capital city of West Sumatra located near the Mentawai island predicted to face a major Earthquake and Tsunami in the future. Past paleogeodetic, paleotsunami, and geodetic investigations [3] indicate that the Mentawai segment of the Sunda subduction zone can host a large tsunamigenic event with magnitude $>8.5$ and a recurrence period of about 200 years. The last major tsunamigenic earthquakes events in this area were in 1797 and 1833 [4], while two recent events, Mw 8.4 and Mw 7.9, occurred near Bengkulu on 12 and 13 September 2007. On 30 September 2009, an earthquake with magnitude 7.6 occurred on the Sumatran subduction, right in front of the Pariaman city. Ismail, F.A., et al.[5], stated that a segment about $300 \mathrm{~km}$ long between the Nias segment and Bengkulu segment, called seismic gap has the potential to trigger a big earthquake in the future.

Besides, by realising the fact that Earthquake and Tsunami are unpredictable, the people of Padang City must be ready and prepared to face the risk of the earthquake and tsunami disasters. By 2019, the government and Regional Disaster Management Agency (BPBD) of Padang City already took various initiatives to reduce the risk of the disasters. The government of Padang build 3 shelters for evacuation in Ulak Karang, Parupuk Tabing, and Tabing with the capacity of about 5.000 people of each shelter and also with 58 buildings that can be used as a temporary evacuation site. They also set up about 30 small billboards consisting of information about disaster preparedness, made posters about disaster preparedness, conducted counseling to 150 schools located in the prone zone, and made tsunami-safe zone signs on 22 roads in Padang.

The Padang city government has taken many disaster risk prevention measures. Then how about the community? Did they already prepare themselves to face the disaster?. To reduce the risk of disaster, the importance of "Self-help" and "mutual-help" can be the best way to help the people to know "what did they not do?" and "how can they do it?" to protect themselves from disasters. Therefore, this research will use the "self-help" and "mutual-help" parameters to analyse the Padang city

* Corresponding author: junaidi@eng.unand.ac.id 
community's preparedness to face the Earthquake and Tsunami disaster.

\section{Methodology}

\subsection{Questionnaire}

Table 1. List of 20 questions in the questionnaire.

\begin{tabular}{|l|l|}
\hline & \multicolumn{1}{|c|}{ Self-help questions } \\
\hline Q1. & $\begin{array}{l}\text { You already know about the fault map, earthquake, } \\
\text { and tsunami potential map (including information } \\
\text { on intensity, liquefaction, and tsunami risk) in the } \\
\text { area where you live. }\end{array}$ \\
\hline Q2. & You have secured your house against earthquakes. \\
\hline Q3. & $\begin{array}{l}\text { You have put the furniture in your home in a safe } \\
\text { place to prevent it from falling during an } \\
\text { earthquake. }\end{array}$ \\
\hline Q4. & $\begin{array}{l}\text { You and your family do not sleep in places where } \\
\text { furniture, shelves, broken lamps, or glass can fall } \\
\text { on you in the event of an earthquake. }\end{array}$ \\
\hline Q5. & $\begin{array}{l}\text { You can protect yourself; especially your head, at } \\
\text { the moment of the earthquake. }\end{array}$ \\
\hline Q6. & $\begin{array}{l}\text { You can evacuate to a higher place without } \\
\text { hesitation in case of a severe earthquake while } \\
\text { visiting or living close to the sea, even if nobody } \\
\text { else does }\end{array}$ \\
\hline Q19. & $\begin{array}{l}\text { You have read and understood the signs or } \\
\text { information about disaster preparedness provided } \\
\text { by the government on every road in your } \\
\text { neighbourhood. }\end{array}$ \\
\hline Q17. \\
Q17. \\
in your neighbourhood.
\end{tabular}

A questionnaire was used in collecting data for this study, either offline or online. The questionnaire consists of 20 questions and also suggestions or comments from the community about the management and mitigation system in Padang city. In this questionnaire, respondents were asked to answer the questions using three choices (Yes, Maybe, and No). The list of questions shown in Table 1

These 20 questions are inspired by the questions from Disaster Reduction Class Application developed by Prof. Akiyoshi Takagi from Gifu University, which focused on "self-help" and "mutual help".

\subsection{Data Sampling}

The sampling method used in this research is purposive sampling. The sample size is determined by using the Yamane [6] formula below :

$$
n=\frac{N}{1+N(e)^{2}}
$$

Where,

$\mathrm{n}=$ sample size

$\mathrm{N}=$ population size

$\mathrm{e}=$ level of precision $(0.05)$

As the population of Padang was 939,112 persons (BPS, 2018), the sample size would be about 400 respondents. These respondents were divided into two survey methods. The first is by direct questionnaire for 250 respondents (Pondok area, Purus area, and Ulak Karang are) and the second is an online questionnaire for 150 respondents (Random area). Then, the respondent's information such as gender, age, educational background (started from didn't pass elementary school until college graduates), and job background are obtained randomly to see the variety of the respondent.

\subsection{Data Analysis}

Each answer in the three-point Likert scale was given a score shown in Table 2. [7]

Table 2. The score is assigned to the Likert response.

\begin{tabular}{|l|l|l|l|}
\hline No. & Answer & Code & Score \\
\hline 1 & No & 1 & 0 \\
\hline 2 & Maybe & 2 & 2 \\
\hline 3 & Yes & 3 & 5 \\
\hline
\end{tabular}

The prepared or not prepared respondents were calculated based on the final score of each respondent. First of all, we estimate the highest total score and lowest total score and then calculate the range. The range was divided by the number of categories to obtain an interval for each category. The value of scoring criteria used to determine the criteria of the respondents by using the formula below:

$$
\text { Total score }=5 \times 20
$$$$
\begin{array}{ll} 
& =100 \\
\text { Final Score } & =\Sigma \text { score }(q 1+q 2+\ldots+q 20)
\end{array}
$$

Then, Determine the scoring on objective criteria, whether the respondents are "prepare" or "not prepare" Range $(\mathrm{R}) \quad=$ highest score - lowest score 
Category $\quad=2$, "prepare" and "not prepare" Interval (I) = Range (R) / Category (C)

Scoring Criteria $=$ Highest score - Interval

Those with a total score $\geq 50$ would be expected to be prepared and those with a score $<50$ might be not prepared. It is also possible to check every response for each question, whether the respondents are prepared to face the disaster or not using formula (3).

Final Score of Question- $\mathrm{n}=(\Sigma$ score Q-n $) /($ Total respondent) (3) $\mathrm{n}=$ Number of the question

If the final score for each question was $\geq 2.5$, we expected the respondent's preparation for this item already been satisfied. On the other hand, if the final score was $<$ 2.5 , expected as not prepared.

\section{Result and Discussions}

\subsection{Result}

This study was based on a questionnaire survey conducted offline and online with 400 respondents in total. The online survey collected 150 data from people who live in Padang (a Random area in Padang), and the direct survey collected 94 data in the Purus, 85 data in Pondok, and 71 data in Ulak Karang. The 400 respondents used in this study were collected randomly and came from different backgrounds. The respondents are Male and Female ranging from ages 17 to 78 years. From collected data, the gender variety of the respondents in this research, as shown in Fig.1. are balanced between Male and Female respondents. Male respondents are 200, and female respondents are 200 persons.

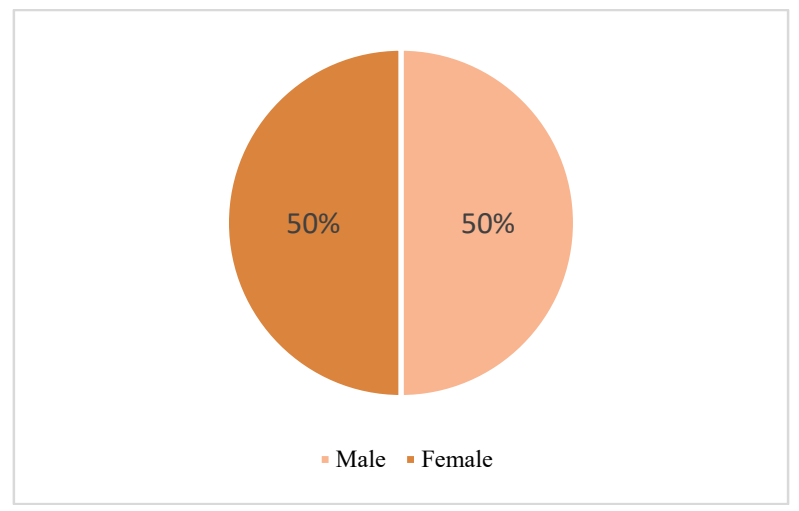

Fig. 1. Gender Variety of 400 Respondents.

For the educational background, as shown in Fig. 2., most of the respondent's educational background in this study was senior high school graduates (198 respondents) and college graduates (161 respondents). Then the rest is junior high school graduates (32 respondents), elementary graduates ( 7 respondents), and did not pass elementary school (2 respondents). For the job background, as shown in Fig. 3., most of the respondents in this research are Private Employee/Entrepreneur with 148 respondents and Student/College Student with 113 respondents. Then the rest is other jobs (49 respondents), housewives (44 respondents), PNS/Ex PNS (41 respondents), Farmer (3 respondents), and POLRI/TNI/ Ex POLRI\&TNI (2 respondents). By knowing the variety of 400 respondents, the author then analyses the preparedness of each respondent facing the earthquake and tsunami disasters. Fig. 4. shows the percentages of 400 respondents preparedness to face earthquake and tsunami disasters.

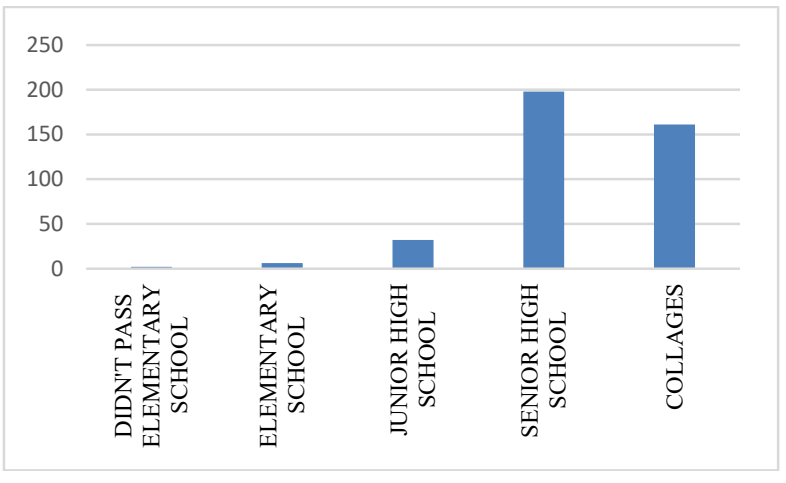

Fig. 2. Educational Background of 400 Respondents.

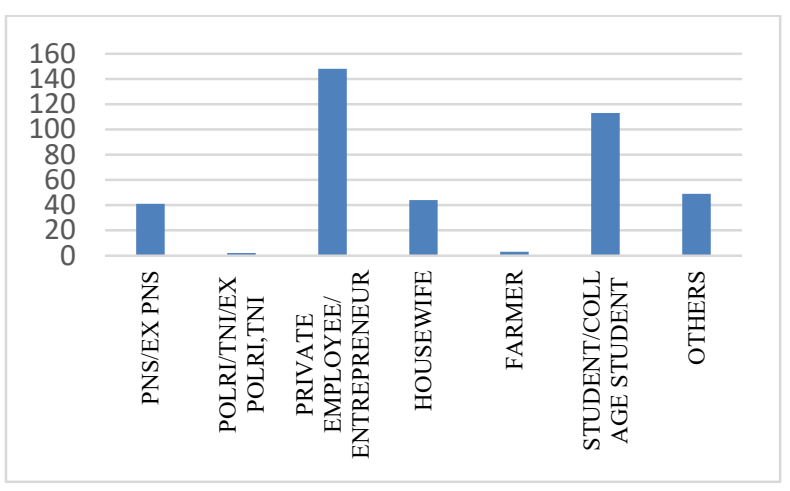

Fig. 3. Job Background of 400 Respondents.

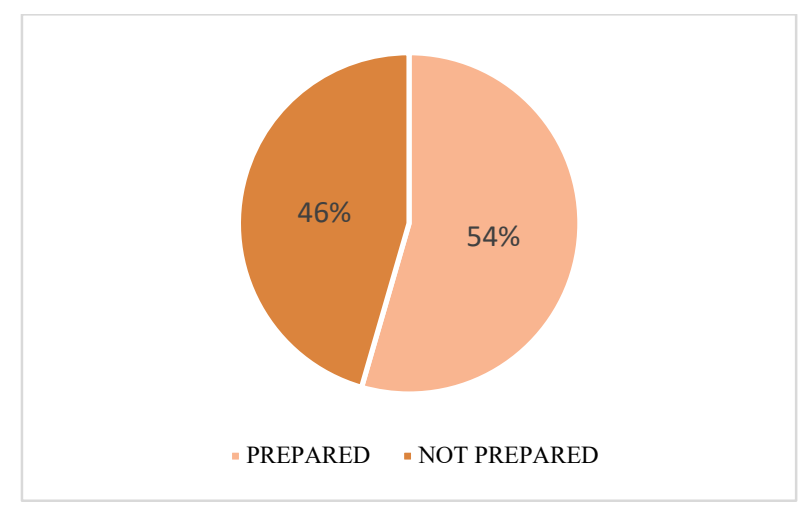

Fig. 4. Job Background of 400 Respondents.

From Fig. 4. above, it can be seen that $54 \%$ of the community are prepared to face the earthquake and tsunami, while $46 \%$ are not prepared. These percentages show a slight difference between prepared and not prepared respondents to face earthquake and tsunami disasters. The gap is only $8 \%$ of both prepared and not prepared. Then, from the result of each score on the option "Yes, Maybe, and No" in the questionnaire, we can see the community level of preparedness for each question. Fig. 5. below will show the level of preparedness from the 20 questions by 400 respondents of Padang City Community. 


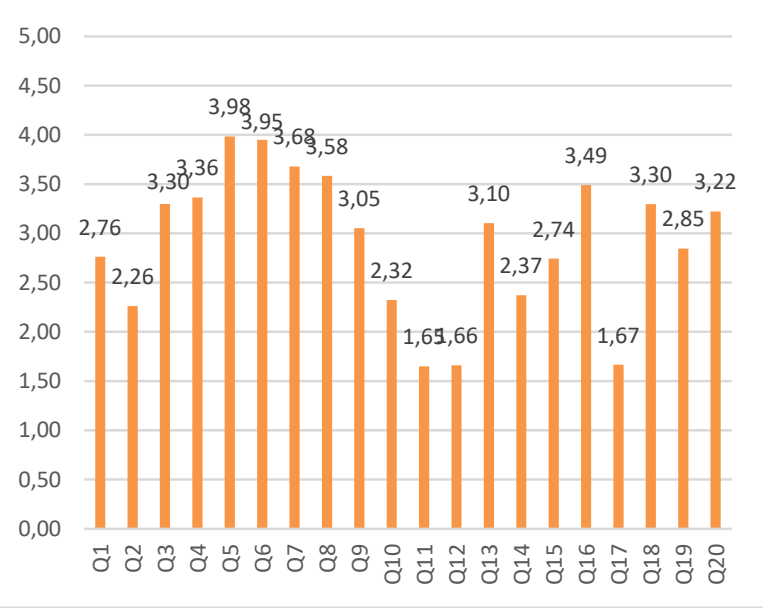

Fig. 5. Level of preparedness from the 20 questions by 400 respondents of Padang city community.

Based on Fig. 5, Padang City Community is most prepared in question number 5 "You can protect your body especially your head, at the moment of an earthquake", where the final score in this question is 3.98. Respondents mostly choose "Yes" in this question, which is means that most of the respondents already know how to protect themselves during the earthquake. However, the final score still did not reach the highest score (5 points), which is means there are still some people who hesitate and do not know how to protect themselves from the earthquake. On the other hand community of Padang city is most unprepared in question number 11 "You and your family have enough food to survive for about a week without gas, electric power, and tap water if a disaster occurs". The fact that the average score in this question is only 1.65, it seems like most of the Padang city community still lacks in the preparation of food reserves when a disaster occurs.

To see more clearly on what questions the Padang City community is more prepared or less prepared based on the questions, the author will separate the data as "Questions with the level of preparedness $\geq 2.5$ " and "Questions with the level of preparedness $<2.5$ ". Fig. 6 . below will show the result of questions with the level of preparedness $\geq$ 2.5.

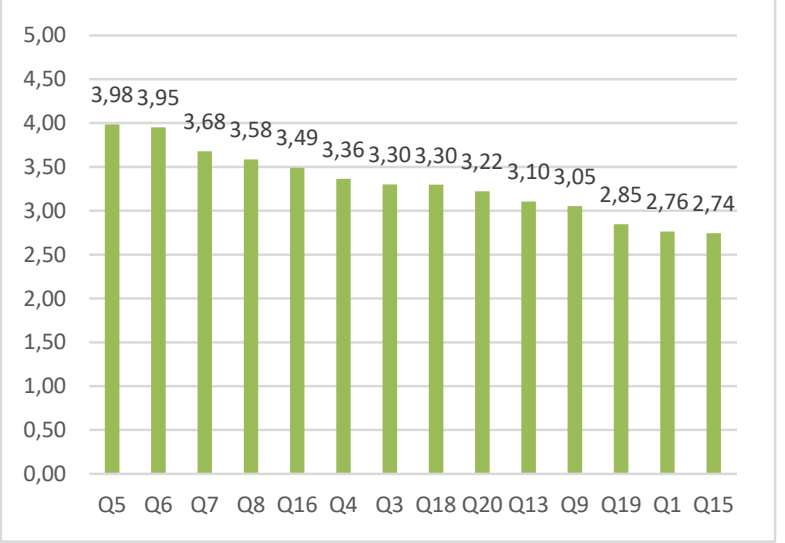

Fig. 6. Questions with Level of Preparedness $\geq 2.5$.

Fig. 6. above shows that the community of Padang city is more prepared on questions number $5,6,7,8,16,4,3$,
$18,20,13,9,19,1$, and 15 in order. According to this result, most of the Padang city Community is already prepared to face the earthquake and tsunami disaster because the average score in each question is more than 2.5. However, these result also shows that not all of the community are prepared because the score on each question is still less than 5 points. It shows that some people still choose "Maybe" and "No" on those questions. Next, the questions with the level of preparedness $<2.5$ can be seen in Fig. 7. below:

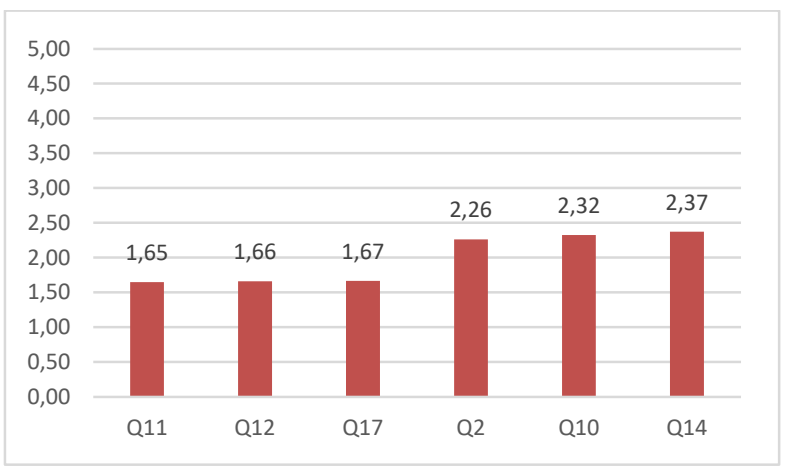

Fig. 7. Questions with Level of Preparedness $<2.5$.

The result shows that the Padang city community is not prepared in Questions 11, 12, 17, 2, 10, and 14. It is because the average score in each question is less than 2.5.

\subsection{Discussions}

The result above shows that 400 respondents of the Padang city community, in general, are still not prepared in terms of "self-help" and "mutual-help". It is because the gap between respondents who are prepared and not prepared are only $8 \%$, and also strengthened by the results shown in Fig. 8. below:

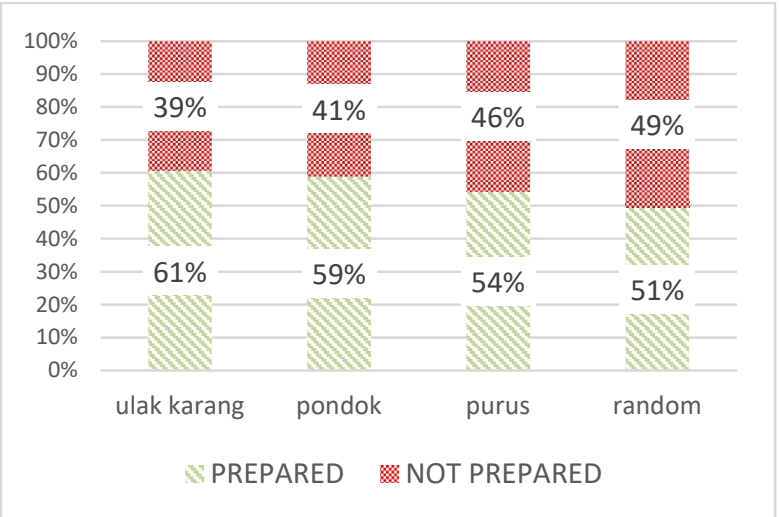

Fig. 8. Data comparison of community preparedness from Random area, Pondok area, Purus area, and Ulak Karang area.

Fig. 8. above shows that by separating the analysis into four different areas (Random area, Pondok area, Purus area, and Ulak Karang area), it can be seen that respondents from the random area in Padang city are more unprepared than the respondent from Pondok, Purus, and Ulak Karang. Respondents from Random areas in Padang city are more representative in terms of Padang city 
community preparedness. It is because these respondents are not only focusing on a specific area in Padang but broader. Also, based on the characteristic of each area, Pondok, Purus, and Ulak Karang used to be more prepared because of these three areas included in the High-Risk Zone (West Padang, North Padang, Nanggalo, and Part of Koto Tangah). Where most of the government programs and policies related to disaster prevention are focusing on these areas. In this study, the result of the selected areas (Pondok, Purus, and Ulak Karang) also shows that around $39 \%-46 \%$ of the community are still not prepared to face earthquake and tsunami disasters. Besides, based on the level of preparedness on the 20 questions, the Community of Random area had the most "Not prepared" questions than the community from Ulak Karang, Pondok, and the Purus.

Also, according to the result of "Not prepared" questions by 400 respondents of Padang city community that shown in Fig. 7, questions 11, 12, 17, 2, 10, and 14 are the important questions related to disaster preparedness. Alhadi and Sasmita [8], stated that the efforts that can improve the community preparedness are using the methods based on the local wisdom of the community, wherein community preparedness requires an active role from the communities. The role of those communities according to Alhadi and Jelita [9], starts from the smallest forms of participation in disaster preparedness which is self and family preparedness. While in a broader scope it includes community groups or community organisations. We can see those questions 11 , $12,17,2,10$, and 14 above are included in this explanation.

This statement is also supported by LIPIUNESCO/ISDR [10] which developed a framework for studying community preparedness to anticipate natural disasters. According to the study, There were 5th critical factors of preparedness to anticipate natural disasters, especially earthquakes and tsunami. Two of the 5th parameters of the critical factors consist of some variables related to question $11,17,12,2$, and 10 . The first parameter mentioned knowledge and attitude towards disaster risk. One of the variables in this parameter is "an understanding of the vulnerability of physical buildings and facilities essential for disaster emergencies" which is related to question number 2 "You have secured your house against earthquakes.". Then, the third parameter mentioned plans for disaster emergency activities, at this point, several variables related to questions $11,17,12$, and 10. The first variable is about disaster management organisations including disaster preparedness agencies, which related to question number 17 "Your neighbourhood has a disaster preparedness training agency.". The second variable is about plans for providing basic needs, including food, drinks, clothing, shelter/camps, clean water, toilets and environmental sanitation, health, and information on disasters and victims, which is related to question number 11 . Then, the last variable related to question 12 and 10 about evacuation equipment and supplies as well as essential facilities for emergencies.

Also, from the past earthquake event that occurred in west Sumatera especially in Padang city in 2009, many problems happened a week after the disaster because people did not prepare themselves for the post-disaster related to questions $11,12,2$, and 10 . As reported in the Liputan 6 newspaper on 5 October 2009 [11], the distribution of aid (food, medicine, lighting, tend, and others) is not distributed evenly by the government to the community so that people end up looting. Also, many houses collapsed because most people did not secure their houses from an earthquake. If the community can provide their own basic needs, especially food and lightning reserves for post-disaster, the problem that happened in 2009 can be minimized. Unfortunately, based on the result that most of the community is still not prepared in questions $11,12,2$, and 10 , we can say that the problem in 2009 can still happen in the future.

According to question number 17 Indonesian government to involve the community participation in disaster management at the kelurahan or village level has been carried out by launching policies and programs aiming to gather local knowledge (local wisdom) about the disaster and improve the preparedness of the community/community in disaster risk areas. Desa Tangguh Bencana (DESTANA) initiated by The National Disaster Management Agency (BNPB) and Kampung Siaga Bencana (KSB) by the Minister of Social Welfare is one of the programs which involve local communities in disaster risk management.

In Padang city, one of the efforts to involve local communities in disaster management is the establishment of Kelompok Siaga Bencana (KSB) in each Kelurahan/village. Simandalahi, T. [12] stated that the Padang City Government has formed and inaugurated the KSB that consists of 2,080 members in 104 kelurahan/villages of 11 regions in Padang city. This program was initiated by The Regional Disaster Management Agency (BPBD) in 2011. Anam et.al [13] stated that the function of the KSB is an extension of the BPBD in monitoring the disaster situation in kelurahan/village. So, the local communities can report the potential and signs of disaster to BPBD through the KSB. However, Anam et.al. [13] also stated that since the formation of KSB in 2011, the presence of the KSB has not been able to achieve expectations. Alhadi and Jelita [9] also stated that since 2011, the existence of the KSB has not been seen. In 2017, the Mayor of Padang issued instructions No. 800.83/BPBD-Pdg/II/2017 concerning the Formation / Activation of KSB as one of the efforts to reactivate the Disaster Preparedness Group that already formed but did not active or vacuum. This instruction is intended for Kelurahan/Village that does not yet have the KSB to be formed immediately. However, Most of the Padang city community chose "No" on question 17 , which means that the existence of KSB still not improved until now. While based the result of question number 14 also shows the Padang city community has a low interest in participating in their community organisation, this result can be one of the reasons why the KSB in Padang is still not progressing.

This study also gathered respondents' comments and hopes regarding the current risk prevention efforts undertaken by the government. The result can be seen in Fig. 9. Below: 


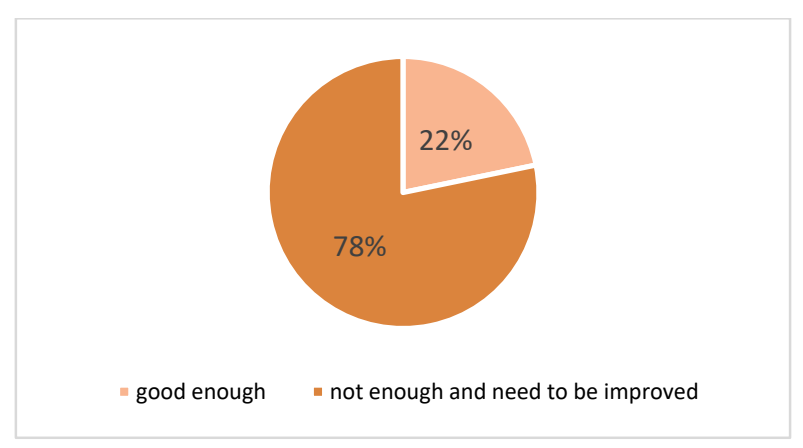

Fig. 9. Padang city community comments regarding the current risk prevention efforts undertaken by the government.

The results show that most respondents said that risk prevention efforts are not enough and still need to be improved. Most of the respondents commented that they wanted the government to increase the information, dissemination, and socialization about disaster preparedness to the community through regular training at least twice a year. They also requested that more shelters be built in high-risk areas because the existents of the shelters are still very limited and have not been maintained until now. It is also clarified by the Study of Kemal, B. M., Yosritzal \& Aulia, Y. B. [14], which stated that vertical evacuation to the existing shelters is not enough because some areas are still not covered with the evacuation plan. Therefore, respondents also suggested the government should provide regulations for any building construction with more than three floors to provide access to the community during the disaster to use it as a temporary shelter. The respondents also hope that the government can provide the community with their basic needs, especially food reserved, medicine, and lightning, to face the earthquake and tsunami in the future.

From this, we can conclude that the community itself still relies heavily on government or public assistance for disaster management. The community still does not realise the importance of "Self-help" and "Mutual- help" having a big impact on disaster prevention. As Harada [15] said, the specific efforts for disaster reduction require a combination of self-help, mutual-help, and government or public assistance. Harada [15] explained that to help oneself when a disaster strikes, everyone must take individual and independent actions to save themselves and their own lives from danger. Next, as for mutual assistance, Harada [15] stated that what is very important in mutual assistance is the formation and maintenance of tight networks based on regular information sharing and collaborative relationships such as neighbourly cooperation in communities and tie-ups between organisations. Lastly, for the government or public assistance, Harada [15] explained that the role of the central government is necessary as a last resort in terms of providing guidance to the community in terms of actions and giving them a sense of reassurance, but there is a sense of distance, to a certain degree, from the natural disaster site. The problem stated by Harada [15] is that since these public institutions are public entities funded by tax money, decision-making often requires a great deal of time and procedures.
Therefore, this research can prove that the Padang city community are still not prepared to face the earthquake and tsunami disaster in the future in term of "self-help" and "mutual-help". The community needs to realise that every individual also needs self-awareness and help each other to face disasters. Then, government policies regarding risk reduction efforts also need to be improved and evaluated.

\section{Conclusions}

A comprehensive study on the preparedness of the vulnerable population in Padang has been conducted using a questionnaire. Preparedness assessed in this study is the application of items in terms of self-help and mutual-help among the community. The data showed that only half of the community could be declared as prepared to minimize the risk when a tsunami hit the city. Data also showed that the most prone communities, such as in Pondok, Purus, and Ulak Karang region, seem to be more prepared than those who are living in another region of the city. Furthermore, from the 20 items of preparation examined, only $70 \%$ of the items can be justified as recognized and prepared by the community. However, the level of preparedness for the items is only about 2.74-3.98 out of a 5-point scale. In terms of preparedness for a disaster, the level of preparedness should be as high as possible. Therefore, the community should increase the level of their preparedness for all items to ensure that the community prepares enough to minimize the loss due to the disaster.

\section{Recommendations}

Based on this study, it was recommended as follow:

1. The community should reduce their dependency on government assistance and be more reliable to selfhelp and mutual-help with people around them.

2. The government should educate and guide the community intensively to increase their awareness and preparedness, especially on how to rely on themself (either self-help or mutual-help) rather than on the help of government officers more.

We would like to thank the lecturers of Civil Engineering at Andalas University and Prof. Akiyoshi Takagi from Gifu University whose provided guidance and information during this research so that this research can be completed properly.

\section{References}

1. T. Ophiyandri, A. Junaidi, A. Takagi, D. Syandriaji, Hazard Risk Management and Mitigation System of Earthquake and Tsunami at Disaster-Prone Area. International Journal on Advanced Science, Engineering and Information Technology, 10 (2020)

2. BNPB. Data dan Informasi Bencana Indonesia. Jakarta, Indonesia: BNPB, 2014. 
3. S. S. Nalbant, S. Steacy, K. Sieh, D. Natawidjaja, and J. McCloskey, Seismology: earthquake risk on the Sunda trench, Nature, 435, 756-757 (2005)

4. D.H. Natawidjaja, K. Sieh, M. Chlieh, J. Galetzka, B.W. Suwargadi, H. Cheng, R.L. Edwards, J.P. Avouac, and S.N. Ward. Source parameters of the great Sumatran megathrust earthquakes of 1797 and 1833 inferred from coral microatolls. Journal of Geophysical Research: Solid Earth, 111(B6), (2006)

5. F.A., Tanjung, J., Hakam, A., \& Boen, T. Plastered Wire-Mesh Bandaged: An Effective Alternative Technique For Seismic Strengthening Of The Unconfined Brick Masonry Housing In Pariaman City, West Sumatera, Indonesia. International Journal of Civil Engineering and Technology (IJCIET), 8 (10), 1001-1008 (2017)

6. Yamane, Taro. Statistics, An Introductory Analysis, 2nd Ed., New York: Harper and Row. (1967).

7. A. Takagi, and Y. Azuma, Web Application of "Disaster Reduction Class" for facilitating understanding and practice for disaster risk preparedness and reduction. World Bosai Forum IDRC Sendai (2017)

8. Z. Alhadi, S. Sasmita. Padang City Community Preparedness in Facing Earthquake and Tsunami Risks Based on Local Wisdom (Study on Disaster Risk Preparedness). Humanus, XIII, .2 Th. 2014.
9. M. Jelita, Z. Alhadi, Factors Affecting the Role of Disaster Preparedness Groups in Realizing Community Preparedness in the City of Padang. Jurnal Ilmu Administrasi Publik, 1, 1 (2018)

10. LIPI-UNESCO/ISDR. Study of Community Preparedness in Anticipating Earthquake and Tsunami Disasters. Covering Earth Sciences Indonesian Institute of Sciences. Jakarta (2006).

11. https://www.liputan6.com/news/read/246478/gempa -dan-bantuan-yang-tersendat

12. T. Simandalahi, Knowledge of the issue of community-based disaster risk reduction in disaster preparedness groups in West Padang District, Padang City. The Indonesian Journal of Health Science, 6 (1) (2016).

13. K. Anam, A. Mutholib, F. Setiyawan, B. A. Andini, \& S. Sefniwati. Readiness of local institutions in dealing with the tsunami disaster: Case studies of Air Manis Village and Purus Village, Padang City. Jurnal Wilayah dan Lingkungan, 6 (1), 15-29 (2018)

14. B. M. Kemal, Yosritzal \& Y. B. Aulia. Evaluation Of Tsunami Evacuation Plans In Padang, Indonesia. International Journal of Civil Engineering and Technology (IJCIET) Technology, 8 (10), 773-780 (2017)

15. H. Harada, Social capital in disaster: From the great east Japan earthquake. The Senshu Social Capital Review, 3, 5-21, (2012) 